\title{
Facebook for Media Relations
}

\author{
Jesus Milton Rousseau S. ${ }^{1}$, Dr. K. Puttaraju², \\ ${ }^{1}$ Research Scholar, Department of Communication, Bangalore University \\ ${ }^{2}$ Professor (Retd.), Department of Communication, Bangalore University
}

\begin{abstract}
The mass usage of Facebook by the new age public relations (PR) professionals has changed the style of media relations in India. Today, PR professionals use Facebook as a tool for media relations. The study investigates on how PR professionals use Facebook for media relations. The research used survey method to collect information from 60 practising young PR professionals across cadres in Bangalore city and interviewed face-to-face 10 of these PR professionals. The study found that majority of the PR professionals (83\%) use Facebook for media relations; they mainly used it to introduce themselves to a journalist, to pitch new story ideas, to chat with journalists, to get journalist's profile details and for relationship building. PR professionals also used Facebook groups, to get journalist's contact information, to get information on journalists swapping jobs, networking with journalists, procuring new media coverage opportunities, to share new story angles and for career opportunities.
\end{abstract}

Keywords: Facebook, Media Relations, Public Relations, Social media, LinkedIn.

\section{Introduction}

The vast adoption of social media by people across ages and regions in India has made sites like Facebook an addiction among youngsters. These social networking sites are invading the style of functioning of almost all the professions. The style of functioning of PR professionals has also changed over a period of time, from the traditional style to the novel style of functioning backed by social media. Even the functioning of the media, their style of writing has changed drastically in the age of social media. Lately 'media relations' which is the integral part of public relations (PR) has been simplified by using social networking sites.

Media relations can be defined as "the systematic, planned, purposeful and mutually beneficial relationship between journalists in the mass media and public relations practitioners. Its goal is to establish trust, understanding and respect between the two groups." (Supa, 2008) James L. Horton, principal at Robert Marston and Associates PR company adds, "Media relations is persuading a generator of content to consider and write about a product, service or issue without paying the content generator to do so. Media relations relies on a practitioner's talent for selling a story through understanding the content generator's preferences, the needs of target individuals and the ability of the media relations practitioner to bring the two together. This, in turn, depends on the content generator's belief in the message-sender's honesty about the product, service or message. If the generator believes the message-sender is fraudulent, he will only publish material that is negative." (Horton, 2009)

Media relations specifically involve building strong relationships with writers, producers, reporters, and editors who are in a position to give coverage for a company. "Media relations is said to be centred around the symbiotic relationship between a PR practitioner and the media most often being described as a journalist, but also, reporter, editor, producer and writer. The majority of the terms used for 'media' are those which uphold a position of power and, ultimately, could be labelled as gatekeepers in the information supply chain." (Kaul, 2013)

The main advantages of using social networking sites for media relations are: Firstly, almost everyone has a profile (account) either in Facebook, LinkedIn, or Twitter; secondly, it's under their true identity with their correct personal details; thirdly, social media is a very personal space where the communication is generally on a one-on-one aspect. Hence, today's young PR professionals who are well acquainted with technology prefer practising media relations through social media, which has emerged as the new style of media relations. With the strides in technological advancements and the new faces of social media a new style of media relations has evolved which can be termed as "Social Media Relations", that is, achieving the purpose of media relations through Facebook, Twitter, LinkedIn, etc.

As everybody wants to use the latest available technology to its maximum benefit in this fast moving world, even senior journalists and reporters agree that the traditional media relations are gradually losing its charm as the newer and easy-to-use media relations approach through social networking sites is garnering its existence.

The traditional style of media relations has changed to the new style of media relations through social networking sites. In the traditional style of media relations, it is the interpersonal style i.e. meeting a reporter 
face-to-face and getting introduced by self-introduction at events/ press conferences or through a common friend's reference or at press clubs, then pitching stories or sending press releases to them and constantly following up via phone or face-to-face meetings to get coverage. Also, simultaneously maintaining a good rapport and pitching to the same reporter with some other unique story ideas. Today, the new style of media relations has simplified the entire process with the younger PR professionals getting introduced to the journalists on Twitter, LinkedIn or Facebook and then they chat with them to build rapport, later send the press releases \& get coverage. Later, pitch new story ideas and get the interactions happen over phone or email with the same journalist. Social networking sites help in building and maintaining media relations.

Pamela Seiple states that "many journalists, reporters, and bloggers make themselves available on Twitter. Using Twitter is a great way to introduce yourself ....... develop relationships by tweeting about an article of theirs you enjoyed or ask how they feel about a particular topic on which they write. Sometimes reporters will also use Twitter to broadcast that they're seeking subjects or sources for a particular story they're writing. If it's a fit for you, reply!...........Facebook and LinkedIn are great ways to maintain relationships with media, but beware: These tools are a little bit more personal than Twitter. Don't start "friending" every reporter you find in your industry. Instead, use Twitter as a way to initiate and grow the relationship. Once the relationship exists, consider connecting on Facebook and/or LinkedIn." (Seiple, 2010)

Jeremy Porter, founder \& editor of Journalistics and a digital communications strategist specializing in digital marketing, social media, demand generation and online public relations, adds "If you have a lot of personal relationships with journalists, Facebook can be an excellent medium for brainstorming story angles with your media (or PR) friends." (Porter, 2010) Also, Sarah Skerik, cites, "In addition to building relationships and establishing another line of communication with key journalists and bloggers, by paying attention to what they share and post, you can learn more about what interests them, and what they've written lately. You may even find a story opportunity amongst the interactions." Further, in her article, she quotes, Andrew Miller, vice president, external communications at Integral Systems, "For the reporters in the Web 2.0 space, I have begun pitching them via Facebook. I have found they often respond quicker to my Facebook messages as opposed to the emails I send to their corporate accounts......... Please note that I have relationships with these reporters and have linked to them on Facebook. For PR people interested in using Facebook as a means to pitch reporters, I suggest doing the same." (Skerik, 2011)

The PR professionals should find out, how the journalist prefers to be contacted? Solis says communication professionals should be familiar with the journalists' preferred form of communication, his or her likes and dislikes. Further he adds, "to genuinely approach blogger relations, or media relations, you must first deconstruct the process of the media ecosystem and reprogram yourself to tap into the basic building blocks of what makes good content and sparks conversations. This, in turn, helps define why people should take the time to speak with you." (Solis, 2009) Also, PR professionals must try to become the 'reporter's reporter' through media relations. Howard lists, "the importance of mastering the basic skills of writing and editing, learning to become a "reporter's reporter" - in other words, don't be afraid to ask questions of the reporter, such as what their needs are - and trying to get a good grasp of what reporters need in order to do their job well." (Howard and Mathews, 2000; Howard, 2004)

Porter also cautions on the use of Facebook for reaching out first time to the journalists, "Facebook is best used for media relations outreach when you have an existing (preferably personal) relationship with a journalist or blogger. If this is your first time reaching out to the journalist, use a different medium - such as phone, email (the most preferred channel by journalists), Twitter or LinkedIn.” (Porter, 2010)

PR professionals can also use inbound media relations, as Porter shares, "You should regularly share information about your work through your status updates, and you just might find that journalists and bloggers will reach out to you for stories. This approach to inbound media relations is becoming more effective as more journalists and bloggers use social networks to research sources for stories." (Porter, 2010)

The skills needed for effective media relations are the same as those needed for good PR. Daney Parker, adds, "The media landscape is changing, but the core skills remain the same. PR officers today should be as comfortable drafting a tweet as they are drafting a press release. They should be equally able to sell in to a journalist or a blogger. He or she should be able to imagine a YouTube storyboard just as they might imagine a feature hitting a national newspaper." (Parker, 2014)

\section{Purpose}

Earlier researchers have explored on the relationship between PR practitioners and journalists, media relations through corporate websites, e-mail in media relations, personal relationships as an important factor in media relations, media catching, and the uses of social media in the PR industry. The present study is the first of its kind to investigate on how PR professionals use Facebook for media relations. The purpose of this research is to explore how world's number one social networking site - "Facebook" helps in the new style of media 
relations. How reporters and PR professionals easily use Facebook as a virtual platform to develop and maintain relations. This study contributes to the emerging body of literature on the new style of media relations.

\section{Literature Review}

Earlier studies have analysed the relationship between PR practitioners and journalists like the studies by Cameron, Sallot, \& Curtin, 1997; Kopenhaver, Martinson, \& Ryan, 1984; Pincus, Rimmer, Rayfield, \& Cropp, 1993; Shin \& Cameron, 2003b; Shoemaker \& Reese, 1991; Tilley and Hollings, 2008; Shaw \& White, 2004.

Few research studies have examined media relations through corporate websites. Alfonso \& Miguel analysed 120 corporate websites from Denmark, France, Germany, Norway, Singapore, Spain, the United Kingdom and the United States and found that large international companies use Web-based media centres or virtual press rooms to achieve their organizational objectives and to meet journalists' demands for information. Also the study showed that most of these virtual press rooms lacked being complete, easy-to-use and are not updated on a daily basis. (Alfonso \& Miguel, 2006) Michael L. Kent and Maureen Taylor discussed on the strengths and weaknesses of corporate websites as a media relations tool. (Kent, 2003) Another study by Reber, \& Kim used content analysis on 74 activist websites and found that one-third used online press rooms. The online press rooms were used for disseminating media relations materials like organizational history, organizational mission statement, organizational publications, press releases and policy papers. (Reber \& Kim, 2006) But Mohamed Kirat noted that only 3 organisations out of the 24 organisations under his study had an online newsroom. Kirat's study concluded that organizations in UAE still have to improve to use the advantages of Internet for effective PR. (Kirat, 2007)

Another study by Duke found that e-mail is vital in media relations and the Web \& e-mail together make it easier to obtain media coverage. Majority of the PR practitioners $(86 \%)$ believed that the Web has improved their PR work. (Duke, 2001)

Today, PR profession needs 2 main skill sets namely, proficiency in writing and media relations. Few studies on PR have highlighted these core competencies. Studies on writing activities of PR professionals were studied by Napoli, Taylor, and Powers (1998). Some of the research studies focused on media relations, but mainly on the traditional style of media relations through face-to-face meetings and informal relations. Shin, J., \& Cameron, G. T.'s study on informal relations cited 11 types of informal relations for media relations, they are: unofficial calls, private meetings, regional/alumni relations, press tours, travels for a press club, bargaining advertising to news coverage, exercising power through managers/ editors of news bureaus, perks including dinner/drinking, activities for friendship such as golf/climbing, presents and free tickets and bribes. The study indicated that even in a culture where press clubs and interpersonal media relations are the norm, attitudinal differences between PR practitioners and journalists are striking. (Shin \& Cameron, 2003a) Samsup Jo and Yungwook Kim in their research work on 'Media or Personal Relations?' in South Korea, reiterated the importance of informal relationships in media relations. The study results emphasized the personal influence model of public relations and stated that personal relationships help in reducing unfavourable media coverage. (Jo \& Kim, 2004) Further, Dustin W. Supa's doctoral thesis on maximizing media relations, found that there has been very little change in the relationship between public relations practitioners and journalists over the past 23 years, even with the advances in education and technology. The study concluded that "In an era when people are more closely connected through technological innovation, it seems as though the relationship between public relations practitioners and journalists has remained static." (Supa, 2008) Also Cho's research work explored on the varying amounts of power PR practitioners had in their interactions with journalists. The survey found that PR practitioners working for health organizations had expert power in media relations (particularly those working for non-profit organizations) as they have frequent communication with reporters, thus developing close relationships with reporters. (Cho, 2006)

Personal relationships is an important factor in media relations, as Erica Swallow states, "No matter which tools PR pros use to connect with media members, the most important factor is the human factor. Public relations and social media are both about creating and fostering relationships. Our PR experts agreed and emphasized the fact that personal relationships will continue to propel the bond between social media and PR." Further in the article, Kelly McAlearney, an account supervisor at Edelman Digital, adds "Regardless of how an announcement is shared - via wire, blog post, tweet, or otherwise - the critical step has historically been, and will remain, the human element. By directly reaching out to key media and influencers with whom we maintain relationships, we're able to ensure their timely awareness of the news." (Swallow, 2010)

With the invasion of technology, a new style of pitching called media catching is becoming popular. In media catching, the journalists try to contact many PR practitioners to get information for their stories e.g. HelpA-Reporter-Out (HARO) website. Waters, Richard D., Tindall, Natalie T. J., \& Morton, Timothy S. analyzed the phenomenon of "media catching," a reversal of the traditional media relations' communication patterns. The study conducted a content analysis of 3,106 reporter requests sent through the HARO and media related 
Twitter updates from HARO founder for 6 months and explored which individuals and media outlets are using media catching to obtain information. The study found that traditional news outlets used Twitter, and new media outlets preferred the LISTSERV technology. (Waters, 2010)

Lately, few studies have also explored the uses of social media in the PR industry. A research paper by Kelli S. Burns discussed on the popular social media tools used for PR like blogs, RSS, wikis, podcasts, video sharing sites and social networks. The study found that the most popular form of social media used with clients are videos $(75 \%)$, followed by blogs $(50 \%)$, social net work profiles $(50 \%)$, and podcasts $(41.7 \%)$. Not so popular were RSS feeds $(25 \%)$, wikis $(16.7 \%)$, and Twitter $(0 \%)$. Also, the PR practitioners used social media tools in their personal lives, with blogs being the most popular $(75 \%)$, followed by social network profiles (66.7\%), RSS feeds (33.3\%), wikis (33.3\%), videos (25\%), Twitter (16.7\%), and podcasts $(16.7 \%)$. The study concluded that social media offers many opportunities for PR practitioners. (Burns, 2008)

Also, Nina Eyrich, Monica L. Padman and Kaye D. Sweetser revealed that use of technology has made PR professionals' job easier by expediting the circulation of information to reach broader audiences. Social media not only allows public relations practitioners to reach out to and engage their publics in conversation, but also provides an avenue to strengthen media relations. The study found that PR practitioners used 6 of the 18 social media tools listed; the most popular was e-mail followed by intranet, blogs, video conferencing, podcasts. (Eyrich, 2008)

In 2010, Mike Sachoff in an article, cited $43 \%$ of journalists have been pitched through social networks, compared to $31 \%$ in 2009. (Sachoff, 2010) Porter also states that $70 \%$ of journalists use social networks to assist in reporting, compared to $41 \%$ last year. (Porter, 2009) And Greer cites examples of few journalists who have asked PR professionals to pitch him on his Facebook "wall," which is something like their bulletin board. (Greer, 2008)

Vineet Kaul, concludes, "Though new media has opened up doors for direct interaction between the PR community and its target audience, it is still an area that needs to justify its appropriateness in current PR practice. Perhaps in the future, as the media landscape evolves and print media matures, this relationship will become more opportune.” (Kaul, 2013)

\subsection{India}

There are not many Indian research studies in this area of research, only few generic PR studies with a small portion of the research focusing on media relations were found. Nilanjana Bardhan and Krishnamurthy Sriramesh stated, media relations through the use of the personal influence models turned out to be the most common public relations activity. The human and interpersonal aspects of the relationship between PR professional and journalists are accorded high value. Frequent press visits, get-togethers and even interactions that may cross the professional line are considered appropriate in Indian public relations. Also, the study stated, PR through personal contact is the most effective means of communication. Although reliance on the media is necessary for communicating public relations messages, interpersonal relationships with key influencers are considered equally, if not more, important. The study found that, media relation was the primary focus of the public relations efforts of all the organizations. (Bardhan \& Sriramesh, 2006) Another study by Seow Ting Lee and Mallika Hemant Desai studied on the media relations in 296 NGOs from India. The study found that "an organization's dialogic orientation has a positive impact on media relations knowledge and strategy but not on the action dimension that focuses on providing information subsidies to journalists." (Lee \& Desai, 2014)

The present study is the first of its kind, as this research study primarily focuses on media relations through one of the social networking sites, namely, Facebook. The invasion of social media is a boon to all the professions. Thus social media has given immense scope for media relations in PR and is gaining prominence as the new style of media relations. The study contributes to the emerging body of literature on media relations, public relations and social media.

\section{Objectives}

1. Do PR professionals use Facebook for media relations?

2. How does Facebook help in media relations?

3. How do Facebook PR groups help in media relations?

4. What is the future of Facebook for media relations?

\section{Methodology}

The present research study requires first hand PR experience and perspectives from the practicing PR professionals; so interview and descriptive survey methods were determined as the best research tools to collect data. The descriptive survey method is the most effective way to collect information across regions by saving time and money. Also survey method shows the true dynamics of the study as the PR professionals participating are assured of their confidentiality and hence encourages accurate and true responses to the questions in the 
questionnaire. The survey method was backed by personal interviews to provide deeper insights in to the present area of research.

A multi-page questionnaire was prepared with both open-ended and close-ended questions covering all the aspects of the research questions cited above. The close-ended questions used Likert scale which ranged in a 5 point scale from 'Never' to 'Always' (Never, Rarely, Sometimes, Often or Always), wherein the respondents had to tick any one of the options only. The questionnaire was sent via e-mail randomly to 75 practising PR professionals across cadres in Bangalore and only 60 completely filled questionnaires were selected for the research. Among them 10 PR professionals were personally interviewed face-to-face to gather deeper insights in to the topic of research.

\subsection{Demographic Profile}

\section{Analysis And Discussion}

For the present research study, the sample size was 60 practising PR professionals across Bangalore city. Gender wise the sample had more females $(n=35,58 \%)$ than males $(n=25,42 \%)$; and Half of the respondents $(n=30,50 \%)$ were between the age group of 26-30 years, 33\% $(n=20)$ were between the age group of 20-25 years, and $17 \%(\mathrm{n}=10)$ were above 30 years. Among the sample majority of them were post graduates $(n=45,75 \%), 17 \%(n=10)$ had completed their PG diploma, and $8 \%(n=5)$ were with their Bachelors degree.

Designation wise, the sample had 25\% $(n=15)$ of Account Executive, 25\% $(n=15)$ Senior Account Executives, 18\% $(\mathrm{n}=10)$ Managers, and Assistant Account Executives, Assistant Managers, Senior managers and Directors were $8 \%(n=5)$ each respectively.

\subsection{Internet \& Facebook usage}

Majority of the sample ( $n=25,42 \%)$ spent $1-3$ hours browsing the web per day, $33 \%(n=20)$ browse it for 3-5 hours, while $25 \%(n=15)$ spend 5-8 hours on the web per day. Also most of them $(n=50,83 \%)$ accessed internet from their mobile/ smart phones.

On Facebook usage, majority of the respondents $(n=45,75 \%)$ spent less than an hour on Facebook per day, while the rest $25 \%(n=15)$ spent $1-3$ hours per day.

\subsection{Is Facebook used for media relations?}

Majority of the PR professionals in this tech savvy world use Facebook for media relations. All the respondents $(n=60,100 \%)$ used Facebook for media relations. With the increase in adoption of technology by the younger PR professionals, this result clearly substantiates use of social networking sites like Facebook for media relations to help ease their PR job. A senior PR professional justifies, "Since, we have access to Facebook on our smart phones today, I keep checking Facebook status updates and feeds frequently, which indirectly helps me to do media relations as I get many story opportunities from Facebook friends (journalists and other PR professionals) and Facebook PR groups via feeds on my Facebook account instantly."

\subsection{Facebook for media relations}

Facebook has aided the young PR professionals in multiple ways to achieve impactful media relations (see Fig. $1 \&$ TABLE 1). More than 25\% $(n=15)$ of the PR professionals use Facebook often to introduce themselves to a journalist, another $25 \%(n=15)$ use it sometimes, while other $50 \%(n=30)$ reported that they rarely use it for introducing themselves to a journalist. Some PR professionals still feel Facebook was not the appropriate channel to introduce themselves to journalists, compared to face-to-face or telephonic interactions, as face-to-face meetings add more credibility in India. Few PR professionals felt Facebook can be used after they had met the journalist at least once or had interacted over phone or e-mail. But, when the journalist is based in another city, Facebook helps in unmasking the journalist with whom the PR professional had interacted over phone or e-mail; a leading PR agency manager adds, "Facebook puts face to a journalist you have never met."

Almost $41.67 \%(n=25)$ of the PR professionals rarely use and 33.34\% $(n=20)$ never use Facebook to meet a journalist face-to-face; while only $16.67 \%(n=10)$ use Facebook often to meet journalists and $8.34 \%$ $(n=5)$ used it sometimes for the same. Still Facebook is not the preferred mode of communication with journalists in India to meet them face-to-face, as few PR professionals stated using phone was a better way to meet a journalist, due to its personal and instantaneous nature.

Facebook was used often by $33.34 \%(n=20)$ and sometimes by $33.34 \%(n=20)$ of PR professionals to pitch new story ideas to journalists, while $16.67 \%(n=10)$ rarely and another $16.67 \%(n=10)$ never used it for the same. Since, the PR professional was already connected to the journalist on Facebook; it was easier to pitch new story ideas on Facebook, as they could get the feedback faster on whether the story ideas were feasible.

Majority of the PR professionals i.e. never by $33.34 \%(n=20)$ and rarely by $50 \%(n=30)$ use Facebook to fix face-to-face or telephonic interaction with a journalist; while $8.34 \%(n=5)$ always used Facebook for it and another $8.34 \%(n=5)$ sometimes used it. Facebook wasn't considered as a suitable channel by PR 
professionals for fixing face-to-face or telephonic interaction with journalists, as the PR professionals were not sure when the journalist would check the Facebook message and they would get confirmation, hence phone was a preferred choice.

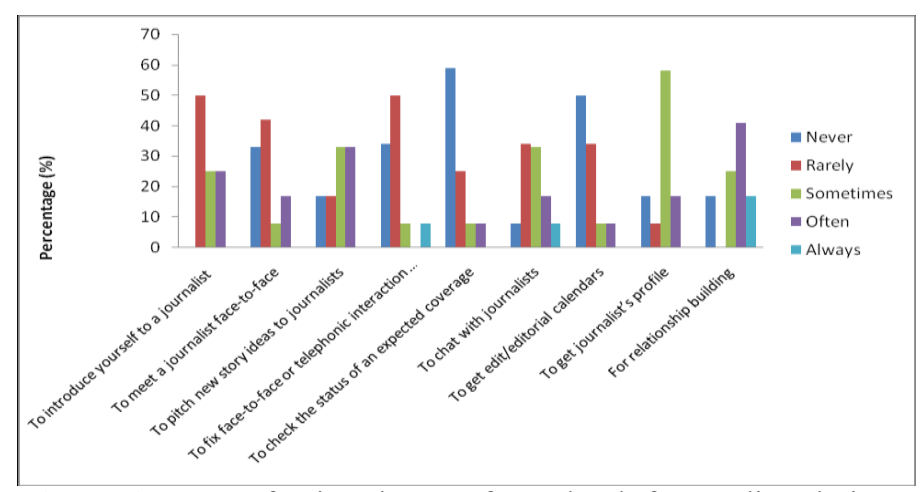

Figure 1: PR professionals use of Facebook for media relations.

Majority of the respondents didn't use Facebook to check the status of an expected coverage. Almost $58.34 \%(\mathrm{n}=35)$ of the PR professionals claimed they never used and $25 \%(\mathrm{n}=15)$ rarely used Facebook to check the status of an expected coverage, while $8.34 \%(\mathrm{n}=5)$ sometimes and another $8.34 \%(\mathrm{n}=5)$ often used Facebook for the same. PR professionals did not prefer Facebook to interact with the journalist to check the status of an expected coverage, as they felt journalists may get irritated.

Most of the PR professionals liked to use Facebook to chat with journalists. Almost 33.34\% $(n=20)$ of the PR professionals sometimes used Facebook to chat with journalists, $16.67 \%(\mathrm{n}=10)$ used it often and another $8.34 \%(\mathrm{n}=5)$ used it always. While $33.34 \%(\mathrm{n}=20)$ rarely used Facebook for chatting with journalists and another $8.34 \%(\mathrm{n}=5)$ never used it for the same. Facebook chatting was considered by PR professionals as one of the easiest ways to maintain relationship with the journalists. The chatting topics ranged from personal incidents to the journalist's recent articles.

Half of the PR professionals claimed they never $(n=30,50 \%)$ use Facebook to get edit/editorial calendars and 33.34\% $(n=20)$ rarely used and $8.34 \%(n=5)$ sometimes used; while $8.34 \%(n=5)$ often used Facebook for the same. E-mails were preferred to collect edit/editorial calendars.

Facebook was used sometimes to get journalist's profile details. Almost $58.34 \%(\mathrm{n}=35)$ sometimes used Facebook to gather journalist's profile information, $16.67 \%(\mathrm{n}=10)$ often used it, while another $16.67 \%$ $(\mathrm{n}=10)$ never and $8.34 \%(\mathrm{n}=5)$ rarely used it for the same. There were 2 ways of collecting journalist's profile details identified, the first method was the PR professional would access the 'About' section of the journalist's Facebook profile and copy the details, the second method was to ask few details directly to the journalist via chatting or messages on Facebook.

Facebook was primarily used for relationship building. Majority of the PR professionals, that is $41.67 \%$ $(n=25)$ used it often, $16.67 \%(n=10)$ always used and $25 \%(n=15)$ sometimes used Facebook for relationship building. Only $16.67 \%(\mathrm{n}=10)$ never used it for the same. A senior PR executive adds, "Through Facebook instant rapport can be built."

Table 1: PR professionals use of Facebook for media relations.

\begin{tabular}{|c|c|c|c|c|c|c|c|c|}
\hline & Never & Rarely & Sometimes & Often & Always & $\mathbf{N}$ & Mean & SD \\
\hline $\begin{array}{l}\text { To introduce yourself } \\
\text { to a journalist }\end{array}$ & $0 \%(0)$ & $\begin{array}{l}50 \% \\
(30)\end{array}$ & $25 \%(15)$ & $\begin{array}{l}25 \% \\
(15)\end{array}$ & $0 \%(0)$ & 60 & 2.75 & 4.23 \\
\hline $\begin{array}{l}\text { To meet a journalist } \\
\text { face-to-face }\end{array}$ & $\begin{array}{l}33.34 \% \\
(20)\end{array}$ & $\begin{array}{l}41.67 \% \\
(25)\end{array}$ & $8.34 \%(5)$ & $\begin{array}{c}16.67 \% \\
(10)\end{array}$ & $0 \%(0)$ & 60 & 2.08 & 3.95 \\
\hline $\begin{array}{l}\text { To pitch new story } \\
\text { ideas to journalists }\end{array}$ & $\begin{array}{c}16.67 \% \\
(10)\end{array}$ & $\begin{array}{c}16.67 \% \\
(10)\end{array}$ & $\begin{array}{l}33.34 \% \\
(20)\end{array}$ & $\begin{array}{l}33.34 \% \\
(20)\end{array}$ & $0 \%(0)$ & 60 & 2.83 & 3.45 \\
\hline $\begin{array}{l}\text { To fix face-to-face or } \\
\text { telephonic interaction } \\
\text { with a journalist }\end{array}$ & $\begin{array}{l}33.34 \% \\
\quad(20)\end{array}$ & $\begin{array}{l}50 \% \\
(30)\end{array}$ & $8.34 \%(5)$ & $0 \%(0)$ & $8.34 \%(5)$ & 60 & 2 & 4.38 \\
\hline $\begin{array}{l}\text { To check the status of } \\
\text { an expected coverage }\end{array}$ & $\begin{array}{l}58.34 \% \\
(35)\end{array}$ & $\begin{array}{l}25 \% \\
(15)\end{array}$ & $8.34 \%(5)$ & $\begin{array}{l}8.34 \% \\
(5)\end{array}$ & $0 \%(0)$ & 60 & 1.67 & 4.72 \\
\hline $\begin{array}{l}\text { To chat with } \\
\text { journalists }\end{array}$ & $\begin{array}{l}8.34 \% \\
(5)\end{array}$ & $\begin{array}{l}33.34 \% \\
(20)\end{array}$ & $\begin{array}{l}33.34 \% \\
(20)\end{array}$ & $\begin{array}{c}16.67 \% \\
(10)\end{array}$ & $8.34 \%(5)$ & 60 & 2.83 & 3.32 \\
\hline $\begin{array}{l}\text { To get edit/editorial } \\
\text { calendars }\end{array}$ & $\begin{array}{l}50 \% \\
(30)\end{array}$ & $\begin{array}{l}33.34 \% \\
(20)\end{array}$ & $8.34 \%(5)$ & $\begin{array}{l}8.34 \% \\
(5)\end{array}$ & $0 \%(0)$ & 60 & 1.75 & 4.43 \\
\hline $\begin{array}{l}\text { To get journalist's } \\
\text { profile }\end{array}$ & $\begin{array}{c}16.67 \% \\
(10)\end{array}$ & $\begin{array}{l}8.34 \% \\
(5)\end{array}$ & $\begin{array}{l}58.34 \% \\
(35)\end{array}$ & $\begin{array}{c}16.67 \% \\
(10)\end{array}$ & $0 \%(0)$ & 60 & 2.75 & 4.43 \\
\hline $\begin{array}{l}\text { For relationship } \\
\text { building }\end{array}$ & $\begin{array}{c}16.67 \% \\
(10)\end{array}$ & $0 \%(0)$ & $25 \%(15)$ & $\begin{array}{c}41.67 \% \\
(25)\end{array}$ & $\begin{array}{l}16.67 \% \\
(10)\end{array}$ & 60 & 3.42 & 3.44 \\
\hline
\end{tabular}


Further, from TABLE 1, with the mean scores ranging from 1 to 5 , it can de deduced that many PR professionals use Facebook for relationship building (3.42), to introduce themselves to a journalist (2.75), to pitch new story ideas (2.83), to chat with journalists (2.83) and to get journalist's profile details (2.75); while only few use Facebook to meet a journalist face-to-face (2.08), to fix face-to-face or telephonic interaction with a journalist (2), to check the status of an expected coverage (1.67) or to get edit/editorial calendars (1.75). Hence, 'relationship building' was the top priority.

A senior manager from a reputed PR agency sums up as, "Facebook is a part of our daily PR work from posting pictures to event invitations to tracking the coverage. We follow up using Facebook for the media events and received better response than mails or calls."

\subsection{Facebook PR groups help in media relations}

There are many forums or communities formed in Facebook called Facebook Groups. Some of these Facebook groups are meant exclusively for PR professionals, which has been termed in this research as "Facebook PR groups". The commonly used Facebook PR groups by PR professionals in India are: Media Movements, Media List, Journalist Storyboard, People for the PRomise foundation of PR, Talk Digital/ Digital PR/ Social Media marketing, Indian PR Forum, Let's make it big.

Almost 92\% $(n=55)$ of the respondents use Facebook PR groups for media relations. More than threefourth of the respondents were members in multiple Facebook PR groups. All the respondents were members of Media Movements $(\mathrm{n}=55,92 \%)$, followed by $58 \%(\mathrm{n}=35)$ in PR/ Corp Comm/ Journalism Jobs India, Media List by $50 \%(n=30)$, Journalist Story board, Journalists \& PR, India PR Forum with $42 \%(n=25)$ each.

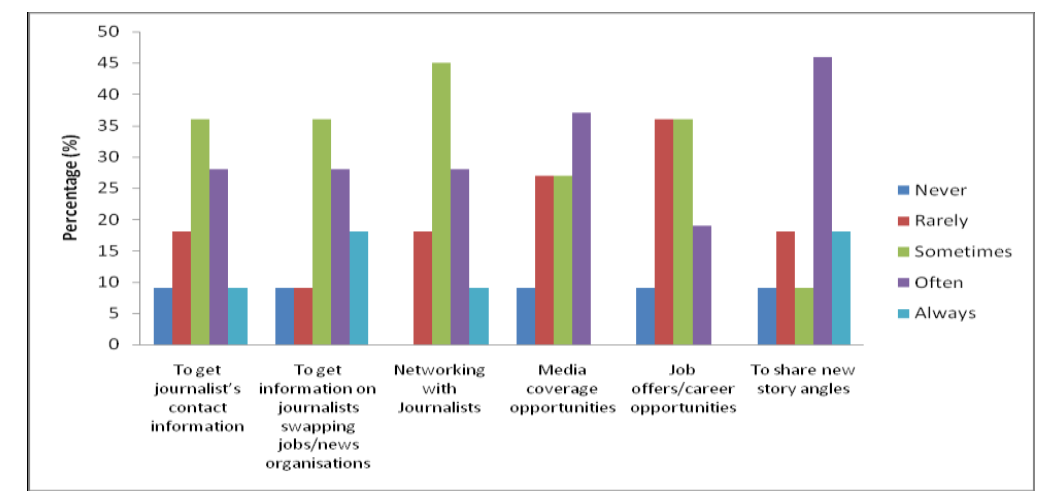

Figure 2: PR professionals use of Facebook PR groups for media relations.

According to Fig. 2 \& TABLE 2, majority of the PR professionals often by $27.27 \%$ ( $n=15)$ and sometimes by $36.36 \%(n=20)$ and $9.09 \%(n=5)$ always use Facebook PR groups to get journalist's contact information; while few $18.18 \%(\mathrm{n}=10)$ rarely and $9.09 \%(\mathrm{n}=5)$ never used it for the same. A senior PR executive adds, "I had posted that I needed a journalist's contact information in Facebook media movements' forum and got instant response from the journalist himself."

Majority of the PR professionals sometimes by $36.36 \%(n=20)$, often by $27.27 \%(n=15)$ and always by $18.18 \%(\mathrm{n}=10)$ used Facebook PR groups to get information on journalists swapping jobs/news organizations; while $9.09 \%(n=5)$ rarely and another $9.09 \%(n=5)$ never used it for the same. Most of these Facebook PR groups had posts from its members regarding journalists swapping jobs, thus informing other members in the forum that a particular journalist has changed his/her job.

Majority of the respondents sometimes by $45.45 \%(\mathrm{n}=25)$, often by $27.27 \%(\mathrm{n}=15)$ and always by 9.09\% $(n=5)$ used Facebook PR groups for networking with Journalists; while $18.18 \%(n=10)$ rarely used. Facebook PR groups were a platform for networking with journalists as it provided opportunities to chat with journalists based in other cities too.

Most of the PR professionals often by $36.36 \%(\mathrm{n}=20)$ and sometimes by $27.27 \%(\mathrm{n}=15)$ use Facebook PR groups for getting media coverage opportunities, while $27.27 \%(n=15)$ rarely and $9.09 \%(n=5)$ never used it for the same. In Facebook PR groups, a journalist posts his requirements for a particular story, the PR professionals directly approach them and the story is done, (also it can be vice-versa). Hence, it is a win-win situation for both - the PR professionals and journalists. A senior manager from a reputed PR agency adds, "I have cracked so many stories using the lead from these Facebook groups."

Job offers/career opportunities were sometimes used by PR professionals. Almost 36.36\% $(\mathrm{n}=20)$ sometimes used Facebook PR groups for Job offers/career opportunities; and 18.18\% $(\mathrm{n}=10)$ often used it; while $9.09 \%(\mathrm{n}=5)$ never used it and another $36.36 \%(\mathrm{n}=20)$ rarely used it for the same. Facebook PR groups helped in 
giving information on vacancies available at various media organisations helping both PR professionals and journalists.

Almost half of the PR professionals often by $45.45 \%(n=25)$ and another $18.18 \%(n=10)$ always and 9.09\% ( $\mathrm{n}=5)$ sometimes used Facebook PR groups to share new story angles; while 9.09\% ( $\mathrm{n}=5)$ never and another $18.18 \%(n=10)$ rarely used it for the same. Facebook PR groups were forums where PR professionals could post their story ideas so that any journalist could accept it.

Table 2: PR professionals use of Facebook PR groups for media relations.

\begin{tabular}{|c|c|c|c|c|c|c|c|c|}
\hline & Never & Rarely & Sometimes & Often & Always & $\mathbf{N}$ & Mean & SD \\
\hline $\begin{array}{l}\text { To get journalist's } \\
\text { contact information }\end{array}$ & $9.09 \%(5)$ & $\begin{array}{l}18.18 \% \\
(10)\end{array}$ & $\begin{array}{l}36.36 \% \\
(20)\end{array}$ & $\begin{array}{l}27.27 \% \\
(15)\end{array}$ & $\begin{array}{l}9.09 \% \\
(5)\end{array}$ & 55 & 3.09 & 2.99 \\
\hline $\begin{array}{l}\text { To get information } \\
\text { on journalists } \\
\text { swapping } \\
\text { jobs/news } \\
\text { organisations } \\
\end{array}$ & $9.09 \%(5)$ & $9.09 \%(5)$ & $\begin{array}{l}36.36 \% \\
\quad(20)\end{array}$ & $\begin{array}{l}27.27 \% \\
\quad(15)\end{array}$ & $\begin{array}{l}18.18 \% \\
(10)\end{array}$ & 55 & 3.36 & 2.92 \\
\hline $\begin{array}{l}\text { Networking with } \\
\text { Journalists }\end{array}$ & $0 \%(0)$ & $\begin{array}{l}18.18 \% \\
(10)\end{array}$ & $\begin{array}{l}45.45 \% \\
(25)\end{array}$ & $\begin{array}{l}27.27 \% \\
(15)\end{array}$ & $\begin{array}{l}9.09 \% \\
(5)\end{array}$ & 55 & 3.27 & 3.52 \\
\hline $\begin{array}{l}\text { Media coverage } \\
\text { opportunities }\end{array}$ & $9.09 \%(5)$ & $\begin{array}{c}27.27 \% \\
(15)\end{array}$ & $\begin{array}{c}27.27 \% \\
(15)\end{array}$ & $\begin{array}{c}36.36 \% \\
(20)\end{array}$ & $0 \%(0)$ & 55 & 2.9 & 3.33 \\
\hline $\begin{array}{l}\text { Job offers/career } \\
\text { opportunities }\end{array}$ & $9.09 \%(5)$ & $\begin{array}{l}36.36 \% \\
(20)\end{array}$ & $\begin{array}{l}36.36 \% \\
(20)\end{array}$ & $\begin{array}{c}18.18 \% \\
(10)\end{array}$ & $0 \%(0)$ & 55 & 2.63 & 3.52 \\
\hline $\begin{array}{l}\text { To share new story } \\
\text { angles }\end{array}$ & $9.09 \%(5)$ & $\begin{array}{l}18.18 \% \\
(10)\end{array}$ & $9.09 \%(5)$ & $\begin{array}{l}45.45 \% \\
(25)\end{array}$ & $\begin{array}{l}18.18 \% \\
(10)\end{array}$ & 55 & 3.45 & 3.21 \\
\hline
\end{tabular}

As seen from TABLE 2, the mean scores ranging from 1 to 5 clearly indicate that majority of the PR professionals use Facebook PR groups to get journalist's contact information (3.09), to get information on journalists swapping jobs (3.36), networking with Journalists (3.27), procuring new media coverage opportunities (2.9), for Job offers/career opportunities (2.63) and to share new story angles (3.45). It can be inferred that 'sharing new story angles' and 'to get information on journalists swapping jobs' was the top priority.

\subsection{Future of Facebook for media relations}

The PR professionals surveyed had a positive viewpoint on the future of Facebook for media relations in India. Facebook is perceived as an imperatively useful media relations tool now and in the future as it helps to reach out to media professionals in an informal setting. An Assistant Manager from a leading PR agency claims, "Lots of traction happens through Facebook these days and the distance between journalists and PR professionals have become thin. Facebook has helped in widening the reach for both the groups." A PR agency manager adds, "Facebook will become a tavern for PR folks and media professionals."

On the other side, few PR professionals feel that media relations through Facebook may soon be swapped by Twitter or WhatsApp. One of the PR Agency managers felt that "Facebook is a fad and is dying out, as people prefer WhatsApp." Also, a PR agency Director adds, "journalists today prefer Twitter or WhatsApp." While another set of PR professionals feel Facebook can be used for media relations only with bloggers and online portal journalists. An Assistant Manager from a PR agency claims, "Facebook is not a medium to build media relations unless it is for online media or bloggers."

The following are the major findings of the study:

\section{Major Findings}

1. Majority of the PR professionals (83\%) use Facebook for media relations.

2. Many PR professionals use Facebook to introduce themselves to a journalist, to pitch new story ideas, to chat with journalists, to get journalist's profile details and for relationship building; while only few use Facebook to meet a journalist face-to-face, to fix face-to-face or telephonic interaction with a journalist, to check the status of an expected coverage or to get edit/editorial calendars.

3. The most frequently used Facebook PR group for media relations was Media Movements with all the PR professionals using it regularly.

4. Majority of the PR professionals use Facebook PR groups to get journalist's contact information, to get information on journalists swapping jobs, networking with journalists, procuring new media coverage opportunities, for job offers/career opportunities and to share new story angles.

5. The future of Facebook for media relations in India seems bright and positive.

6. On the other side, few PR professionals felt that, in future, media relations through Facebook or Facebook PR groups may be replaced by Twitter or WhatsApp. 


\section{Conclusion}

The findings of the study clearly depict that today's PR professionals are tech savvy and use social networking sites like Facebook to simplify their PR job. Facebook and Facebook PR groups help the new age PR professionals to a great extent in media relations. Facebook is ranked as the world's number one social networking site, which substantiates the user base of Facebook in India too. Facebook is used mainly for personal reasons, but lately professionals don't want to use multiple accounts, so they prefer using Facebook only for their profession too. With the advancement in technologies and competitive prices almost all the professionals use smart phones; these smart phones ensure 24/7 Facebook connectivity, hence Facebook has evolved as the medium of choice for media relations by the new age PR professionals and is being widely accepted by the journalists too. Thus, the present study found that majority of the PR professionals use Facebook for media relations, which has emerged as the new style of media relations.

PR professionals often used Facebook to chat with journalists, to pitch new story ideas to journalists and for relationship building. Also, sometimes they used Facebook to introduce themselves to a journalist or to get journalist's profile. Thus, Facebook helped in creating, networking and maintaining relationship with journalists. Thus, using Facebook in media relations helps in boosting the overall productivity of the new age PR professionals.

Majority of the PR professionals (92\%) also use the Facebook PR groups. Media Movements Facebook group was the widely used Facebook PR group for media relations. Compared to other Facebook PR groups, Media Movements group has 19,785 active members.

Most of the PR professionals used Facebook PR groups to get journalist's contact information, to get information on journalists swapping jobs/news organizations, networking with journalists, to get media coverage opportunities, to share new story angles and for job offers/ career opportunities. Thus, Facebook PR groups are the virtual platforms or forums for PR professionals and journalists to exchange story ideas or media coverage opportunities, which is a win-win situation for both the professionals, as the journalist gets his source of information for the story and the PR professional gets the required coverage for their clients.

The vernacular press journalists still don't use Facebook and prefer the traditional style of media relations through phone or e-mail or face-to-face meetings. Here, Facebook or Facebook PR groups supplement the existing media relation tools like face-to-face communication, telephonic interaction or e-mail to build rapport and maintain relationship with journalists, especially with vernacular journalists.

The future of Facebook for media relations in India seems lucrative, but few PR professionals opine that the use of Facebook for media relations may be replaced shortly by Twitter or WhatsApp.

\section{Limitations And Future Research}

This research study has attempted to review the new style of media relations, the vast use of Facebook and Facebook PR groups for media relations, most frequently used Facebook PR groups by PR professionals in Bangalore and the future of Facebook for media relations.

This study also has its limitations, which might influence the generalizability of its findings. The sample size was limited to Bangalore city only; hence the results cannot be generalized across India.

Thus, future research study can be conducted on PR professionals across India. Also, future studies can study on broader aspects like Facebook for public relations, Facebook groups for public relations, Using Facebook for media relations with vernacular journalists, Comparative analysis of Facebook with WhatsApp or Twitter for media relations, Using WhatsApp, Twitter, or LinkedIn for media relations.

\section{References}

[1] Alfonso, G.-H., \& Miguel, R. Trends in online media relations: Web-based corporate press rooms in leading international companies, Public Relations Review, 32, 267-275, 2006.

[2] Bardhan, N. and Sriramesh, K. Public Relations in India Review of a Programme of Research, Journal of Creative Communications 2006; 1; 39, 2006.

[3] Brown, R., Public Relations and the Social Web - How to use social media and web 2.0 in Communications (London, Kogan Page, 2009).

[4] Burns, Kelli S. A historical examination of the development of social media and its application to the public relations industry, Proc. 2008 ICA Preconference, Montreal, Quebec, Canada, 2008.

[5] Cameron, G. T., Sallot, L. M., \& Curtin, P. A. Public relations and the production of news: Critical review and theoretical framework, Communication Year Book, 20, 111-115, 1997.

[6] Cho, S. The power of public relations in media relations: A national survey of health PR practitioners, Journalism \& Mass Communication Quarterly, 83, 563-580, 2006.

[7] Curtis, L., Edwards, C., Fraser, K.L., Gudelsky S., Holmquist, J., Thornton, K., Sweetser, K.D., Adoption of social media for public relations by non profit organizations, Public Relations Review 36 (2010) 90-92, 2010.

[8] Duke, S. Wired science: Use of World Wide Web and email in science public relations, Public Relations Review, Volume 28, Issue 3, August 2002, Pages 311-324, 2002.

[9] Eyrich, N., Padman, Monica L. \& Sweetser, Kaye D. PR practitioners' use of social media tools and communication technology, Public Relations Review 34 (2008) 412-414, 2008.

[10] Greer, Jon. Using Facebook to Do PR, MoneyWatch, CBS News, February 1, 2008. 
[11] Jo, Samsup and Kim, Yungwook. Media or Personal Relations? Exploring Media Relations Dimensions in South Korea, Journalism \& Mass Communication Quarterly, June 2004 vol. 81 no. 2 292-306, 2004.

[12] Kaul, Vineet. PR and the Media: Friends or Foes? Global Media Journal: Pakistan Edition; Spring2013, Vol. 6 Issue 1, p58, March, 2013 .

[13] Kopenhaver, L. L., Martinson, D., \& Ryan, M. How public relations practitioners and editors in Florida view each other, Journalism Quarterly, 61, 860-865, 884, 1984.

[14] Lee., Seow T., Desai, Mallika H. Dialogic communication and media relations in non-governmental organizations, Journal of Communication Management, Vol. 18 Iss: 1, pp.80 - 100, 2014.

[15] Napoli, P. M., Taylor, M., \& Powers, G. Writing activities of public relations practitioners: The relationship between experience and writing tasks, Public Relations Review, 25, 369-380, 1998.

[16] Pincus, J. D., Rimmer, T., Rayfield, R. E., \& Cropp, F. Newspaper editors' perceptions of public relations: How business, news, and sports editors differ, Journal of Public Relations Research, 5, 27-45, 1993.

[17] Shaw, T., \& White, C. Public relations and journalism educators' perceptions of media relations, Public Relations Review, 30, 493$502,2004$.

[18] Shin, J., \& Cameron, G. T. Informal relations: A look at personal influence in media relations, Journal of Communication Management, Vol. 7, 3 239-253, 2003a.

[19] Shin, J. H., \& Cameron, G. T. The interplay of professional and cultural factors in the online source-reporter relationship, Journalism Studies, 4, 253-272, $2003 \mathrm{~b}$.

[20] Shoemaker, P., \& Reese, S. Mediating the messages: Theories of influence on mass media content. (New York, Longman, 1991).

[21] Solis, Brain and Breakenridge, D. Putting the Public Back in Public Relations - How Social Media Is Reinventing the Aging Business of PR, (New Jersey, Pearson Education Inc., Ft Press, 2009).

[22] Supa, Dustin W. Maximizing Media Relations Through a Better Understanding of the Public Relations - Journalist Relationship, doctoral diss., University of Miami, 2008.

[23] Tilley, E., \& Hollings, J. Still stuck in "a love-hate relationship"': Understanding journalists' enduring and impassioned duality toward public relations. Proc. ANZCA Conference, Wellington, New Zealand, 2008.

[24] Waters, Richard D., Tindall, Natalie T. J., \& Morton, Timothy S. Media Catching and the Journalist-Public Relations Practitioner Relationship: How Social Media are Changing the Practice of Media Relations, Journal of Public Relations Research, 22:3, 241264, July, 2010.

\section{Websites}

[1] Greer, Jon, Using Facebook to Do PR. [online] http://www.cbsnews.com/news/using-facebook-to-do-pr/ (1 February, 2008) Horton, James L, The Death of Media Relations? [online] http://www.online-pr.com/ (19 April, 2009)

[2] Lavrusik,V. \& Cameron, B., Study: How People Are Engaging Journalists on Facebook \& Best Practices. [online] https://www.facebook.com/notes/facebook-journalists/study-how-people-are-engaging-journalists-on-facebook-bestpractices/245775148767840 (July 13, 2011)

[3] Parker, Daney, Is media relations still the most important part of PR? [online] http://www.prmoment.com/2472/ismedia-relations-still-the-most-important-part-of-pr.aspx (27 February, 2014)

[4] Porter, Jeremy, Facebook for Public Relations. [online] http://blog.journalistics.com/2010/facebook-for-publicrelations/ (21 January, 2010)

[5] Porter, Jeremy, 70 Percent of Journalists Use Social Networks to Assist in Reporting. [online] http://blog.journalistics.com/2009/70-percent-of-journalists-use-social-networks-to-assist-in-reporting/ (23 September, 2009)

[6] Sachoff, M., More Journalists Using Facebook And Twitter - Journalists relying on social media for stories. [online] http://www.webpronews.com/more-journalists-using-facebook-and-twitter-2010-04 (5 April, 2010)

[7] Skerik, Sarah, Using Facebook for Public Relations. [online] http://blog.prnewswire.com/2011/08/09/facebook-forpublic-relations/ (9 August, 2011)

[8] Swallow, Erica, The Future of Public Relations and Social Media. [online] http://mashable.com/2010/08/16/prsocial-media-future/ (16 August, 2010) 